\title{
Rethinking the message of the church in the 21st century: An amalgamation between science and religion
}

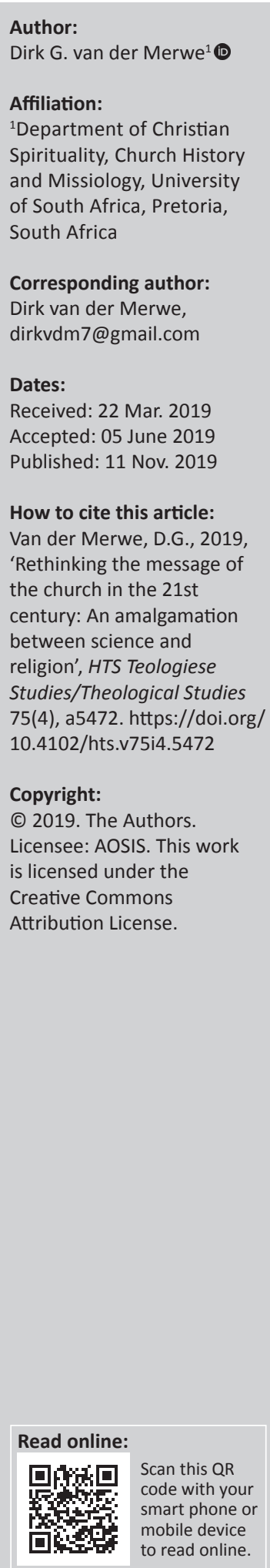

Throughout its history, Christianity has stood in a dichotomous relation to the various philosophical movements or eras (pre-modernism, modernism, postmodernism and post-postmodernism) that took on different faces throughout history. In each period, it was the sciences that influenced, to a great extent, the interpretation and understanding of the Bible. Christianity, however, was not immune to influences, specifically those of the Western world. This essay reflects briefly on this dichotomy and the influence of Bultmann's demythologising of the kerygma during the 20th century. Also, the remythologising (Vanhoozer) of the church's message as proposed for the 21st century no more satisfies the critical Christian thinkers. The relationship between science and religion is revisited, albeit from a different perspective as established over the past two decades as to how the sciences have been pointed out more and more to complement theology. This article endeavours to evoke the church to consider the fundamental contributions of the sciences and how it is going to incorporate the sciences into its theological training and message to the world.

Keywords: Dialectic; Sciences; Theology; Demythologising; Remythologising.

\section{Introduction}

In the period 2017-2018, I had two experiences that contributed to the theme and the way of thinking in this essay. At the end of 2017, the well-known German Theologian, Jurgen Moltmann, visited the Theological faculty of Pretoria and presented a public lecture. An emeritus minister (PhD) from the Dutch Reformed Church was sitting next to me. After Moltmann's lecture, we started a conversation during which he made two questioning-statements: 'In a post-modern era, how do you explain to a literate community or congregation who God is? How do you explain the trinity, especially in a time where science ${ }^{1}$ is so prominent and vigorous?'

My second experience occurred a year later at the end of 2018 after an eventful reading programme where I followed the debates between atheists (mostly scientists) and Christians on scientific and theological level on topics such as: Is there a God? How did creation happen? Was Jesus resurrected? Where do humans come from? and so forth. This reading really stimulated my critical thinking and my wrestling with certain theological issues. It does not mean that I agree or even disagree with everything I have read, but at least it stimulated my thoughts and reasoning about certain issues many Christians have with the Bible. Therefore, this essay is my response to the two instances mentioned above, which also deal with the thesis of this special edition of The church in need of change (Agency). ${ }^{2}$

In order to discuss the two experiences mentioned above that have common ground, I will argue that the church does not dare to continue relying solely on theology to talk about God, Jesus, creation and the Christian life. In order to answer the above questions, the church will have to work at an interdisciplinary level. Other disciplines, especially those of the various sciences, also 1.Computer science, medical science, natural science, biological science, cosmological science and geophysics.

2.Van Aarde (2009:6) points out that institutional Christianity (by implication) cannot simply maintain its status quo in a post-secular world. A logical consequence would not be that Christianity will come to an end and will be replaced by spirituality. The question that arises is 'What then, is the future of the ecclesia as institute?'

3.At this point I want to agree with the view of Vanhoozer (2010:xiv) that 'Christianity is fundamentally neither a philosophy nor a system of morality but a theodrama, a doing in which God gets the most important speaking and acting part'. 
have to be applied to theologically formulate the 'Good News' in a post-modern age. ${ }^{4}$ We are all aware of the fact that the worldview today differs vastly from the worldview of antiquity owing to the phenomenal development and contributions of specifically the natural, biological and empirical sciences. People ask questions about God and religion from a postmodern paradigm. Therefore, an amalgamation between science and religion is critically needed to formulate the 'good news' in order to answer the questions people grapple with

The modus operandi in this essay will be deductive reasoning, moving from a broad background perspective to a specific point of reasoning. The presentation will focus firstly on the dialectic between theology and philosophical discourses in different eras and how these philosophical discourses influence the reading and understanding of the Bible. Secondly, cognisance is taken of Bultmann's demythologising of biblical theology to make it comprehensible and of the remythologising of theology as proposed by Vanhoozer. Thirdly, this essay moves beyond the demythologising of Bultmann and remythologising of Vanhoozer, petitioning the amalgamation of the sciences with theology in the church's reading and explanation of the Bible's message.

\section{The dialectic between theology and philosophical movements}

Throughout its history and existence, Christianity has stood in dichotomous relations with some philosophical movements and $\operatorname{eras}^{5}$ that took on different faces. Christianity, however, was not immune to their influences. On the contrary, Christianity was greatly influenced by movements and eras such as pre-modernism, modernism and postmodernism, which stretched over many centuries and is now approaching postpostmodernism. ${ }^{6}$ During these eras the natural, cosmological, biological and human sciences played major roles. ${ }^{7}$

\section{Many books have been published over the past two decades to attend to this need Many scientists have opened the scientific door to Christianity to compliment theology and many other matters in life: Harris 1992, Jesus as God: the New Testament use of Theos in reference to Jesus; Meyer 2009, Signature in the cell. DNA evidence for intelligent design; Bird et al. 2014, How God became Jesus; Collin 2003, Science and Faith. Friends or foes; Collins, 2006, The language of God. A scientist presents evidence for belief; Newman, Davila and Lewis, 1999, Jewish roots for Christological monotheism; Flew and Varghese 2007, There is a God; Gould (ed.), Beyond the control of God? Six views on the problem of God and abstract objects; Hughes 2005, The nature of God; Kirk 2007, The future of reason, science, and faith. Following modernity and post-modernity; Mahoney 2011, Christianity in evolution. An exploration. Cvetkovic 2001. An Investigation of the concepts of logos in Greek philosophy and Christian thought. These are only a few.}

5.Philosophical movements arose along with cultural trends and changes from widescale and far-reaching transformations in Western Society since the late 19th and early 20th centuries.

6.Although some already have started talking about post-postmodernism (Turner 1996:3-10); pseudo-modernism or digi-modernism (Kirby 2016:1-4) or metamodernism (Vermeulen \& Van den Akker 2010) to follow postmodernism, in this essay the focus will be on post-modernism. The reason is because there is still too much uncertainty whether this is the case. Gibbons (2017:n.p.), involved in Contemporary Stylistics at Sheffield Hallam University, refers to quite a number of terms for this new supplanting cultural logic, a shift in the ruling belief system: 'altermodernism, cosmodernism, digimodernism, metamodernism, performatism, post-digital, post-humanism, and the clunky post-postmodernism'. According to him they complement one another as much as they compete with one another. His him, they complemer. His opinion is the Post it in partly as a result of an oversaturation of the market.

7.See especially the compendium, When Science \& Christianity meet, edited by D.C. Lindberg and R.L. Numbers (2003:4), in which a collection of 12 case histories illustrate a variety of encounters between Christianity and science.
Clayton (2007:91; cf. also Griffin 1989:52) correctly points out that Modernity was the 'period of boundary-drawing'. For him Galileo, Kepler and Newton had access to solid data that helped them to progressively provide trustworthy formulations of natural law. Their understanding of these laws led them and others to an increasing awareness of power regarding natural scientific methodology as acceptable. This resulted in the sciences being declared independent from the limitations of the Christian worldview.

What was played out in fundamental physics and cosmology in the 16th to 18th century was played out in biology in the mid-19th century and in the human sciences a few decades later. Until Darwin, researchers in anatomy, zoology and medicine could acknowledge the ordering, providential hand of God in the biosphere while engaging in their science with de facto independence. From this point on, the biological sciences proceeded as independent fields of enquiry (Clayton 2007:91). The result of the various revolutions, it seemed, was to move humans from a position of ontological primacy and our planet from a position of cosmological centrality. Both were replaced by the frightening immensity of infinite worlds by a universe without a centre and by a blind process of natural selection which left no place for the glory of God (Clayton 2007:92). Science has transgressed no boundaries in dismissing religion, because metaphysics in general and specifically in religion was never a significant (epistemic) force to begin with. All questions are scientific; indeed, every meaningful statement that can be made is empirical (Clayton 2007:94; also Numbers 2003:265). ${ }^{8}$

Each historical period has its specific questions, problems and consequences that deal with its own claims to theology. Theology has an address - the human being of a specific time in a specific culture. If theology does not speak to postmodern people in their idioms and in the intellectual discourse in their domestic cultures and worldviews, theology will no longer have a message for those people and will no longer deal with their wellbeing and answer their timely questions (cf. Heyns 1974:220).

The rest of this subsection will illustrate how philosophical discourses in different eras influenced theology; the interpretation of scripture and the spiritualities that arose from it. It will briefly focus only on the discourse of postmodernity and the paradigm of post-secularism that emanated from postmodernism.

\section{The postmodern discourse}

During the late 20th century, a new philosophical era ${ }^{9}$ emerged in the West. This discourse - referred to as

8. Kirk (2007:22) characterised modernity as "an attempt to build a universally valid explanation of existence from the basis of human reason alone, an intellectually satisfying theory that encompasses everything. It proposes a verifiable view of reality which is not historically contingent, culturally loaded or socially prejudiced, but acceptable to every right-minded thinker'.

9.Thiselton (2006:646) refers to it as a 'postmodern mood'. Others refer to it as an era. 
postmodernity ${ }^{10}$ - also presented challenges to religion (Geaves \& Chryssides 2007:59). According to Vorster (2012), postmodernity 'describes a new condition in Western thought and culture'. For Van Huyssteen (1997:187) and Kirk (2007:18), 'typical of postmodernity is its skepticism concerning the central role assigned to reason and rational thought. Over against indubitable truth-claims, an overconfident faith in science, ${ }^{11}$ and a metaphysical way of reasoning the interrelatedness of truth-perspectives, ethical pluralism and cultural relativism is typical of the postmodern perspective'.

King (2009:202) refers to the effect of postmodernism as one that 'pursues a sceptical deconstruction of all systems of thought'; it questioned all rigid and fixed explanations. It also questioned the necessity of reason as the primary en route to human knowledge. Five years later, Beyers (2014:2) ${ }^{12}$ pointed out that the 'one way' of perceiving existence is now, in the era of postmodernity, replaced by 'heterogeneity, fragmentation and pluralism'. Relativity and subjectivity have now become the two most fundamental perspectives in postmodernism.

As a result, postmodernity proposed multiple ways of generating knowledge in which the intuition became a possible valuable way to add to knowledge (Geaves \& Chryssides 2007:59). Likewise, in the instance of spiritual experiences, postmodernity replaced the dissatisfied mood fostered by modernism for a subsistence of 'desire and fantasy' (cf. Geaves \& Chryssides 2007:60). Postmodernity opens up possibilities for religion through all the features mentioned above and more (King 2009:216; see postsecularism) and a resurgence of spirituality. Unfortunately for religion, lacunae emerged. Postmodernity does not offer a 'hermeneutics of trust that is necessary for religion' (King 2009:202). This contributed to the collapse of the two vital aspects in religion, namely truth and certainty, and led to Postmodernity's abandonment of all security that is based on single claims of truth (King 2009:202). Beyers (2014:2) concurs with this view that a single way of perceiving existence is no longer possible. The effect of this was the emergence of a plurality of truths. King (2009:216) interprets this positively; he does not deem it as a threat to Christianity.

The vantage point of all this is that the postmodern worldview affords the recovery of belief in God. This fosters the adaptation of the traditional idea of God. In modernity, the identity of God was fixed; in postmodernity, the identity of God underwent some changes. God is much more and he is also more incomprehensible than Biblical articulation of the reality and the nature of God. The mystery of the divine,

10.Thiselton (2006:645) adds a new perspective. He sees postmodernity not as a reaction against or modification of modernity in the western tradition of philosophical, scientific and social thought. The optimistic progressivism, its individualism and its claim to universality, indeed provoke many of the characteristic negations and reactions of postmodernity.

11.Numbers (2003:265) introduces his chapter in the compendium, Where science and Christianity meet, with the statement, 'Nothing has come to characterise modern science more than its rejection of appeals to God in explaining the modern science more than its rejection of appeals to God in explaining the educators have made this claim'.

12. Relativism and subjectivism can be added as characteristic of postmodern society (cf. King 2009:202). however, becomes more explicit. The result is an emergence in post-secularism of nurtured new interests in Christian spirituality that has positive implications for the church.

\section{Post-secular paradigm}

Post-secularism emanated from the discourse of postmodernity. Prior to this, the Christian church had been trapped in the dichotomy between the secular ${ }^{13}$ and the sacred for centuries. Secularism emanated during the era of modernism. Today post-secularism exists in a postmodern discourse. Hovorun (2013:423) asserts that post-secularism had initially been interpreted as a social phenomenon. At a later stage, Jürgen Habermas and others attempted to articulate it in philosophical terms (also Vorster 2012). Then theologians also jumped on the bandwagon when they became involved in the conversation. Their motif was to understand how religious people could benefit from this.

A serious complexity the church had to deal with throughout the ages until today concerns the dualism and dichotomy of 'sacred' versus 'secular'. Another and related complexity is the nature of the church's theology. Indisputably, some authoritative theologies were formulated in the modern era. These theologies (ideologies) functioned powerfully and for the largest part of the 20th century in which they ${ }^{14}$ governed the world (cf. Hovorun 2013:427).

In conclusion, the dialectic between theology and these movements is still severe. Although, finding 'ourselves in a postmodern discourse and post-secular paradigm in the 21st century, theology and these movements are still birds of different feathers. Old stereotyped answers (message), patterns of worship, formalisms and traditional boundaries no longer attend to the needs of today' (Van Der Merwe 2017). Postmodernism and post-secularism pose new challenges to Christian theology (cf. Vorster 2012). In a more 'religion-friendly' environment, Christian theology can develop a plausible metatheory or meta-theology for today; it is expected of the church to constitute such an environment. In spite of secularisation, many people are still religious and remain devoted to the church (cf. Taylor 2007:27). Many of these believers expect new and different things from the church, which revolve around one thing - a neo-interpretation and application of Scripture and the need for a neo-theological composition.

The gigantic interest in Christian spirituality ${ }^{15}$ and the effort of reconciling ${ }^{16}$ science and theology over the past three

13.Taylor (2007:20) defines secularisation as that which "consists of new conditions of belief; it consists in a new shape to the experience which prompts to and is defined belief; it consists in a new shape to the experience which prompts to and is defined
by belief; in a new context in which all search and questioning about the moral and the spiritual must proceed'. Taylor (2010:21) also expresses that the understanding of secularism to 'bring about a "death of God"' is unconvincing for him. He verifies this statement later in his book.

14. Hovorun (2013:427) has used here 'ideologies' and 'faith creeds'. The use of theologies' reflects my interpretation.

15.There is a growing interest in the phenomenon of spirituality worldwide. This is evident in the enormous number of publications, both popular and scientific, that are appearing. Experts from the major religious traditions are very productive in their particular spirituality. More and more tertiary institutions worldwide are their particular spirituality. More and more tertiary institutions worldwide are
starting to offer academic programmes on spirituality. Societies for the study of starting to offer academic programmes on spirituality. Societies for the study of
spirituality have been established and academic journals in the field are on the increase (cf. Kourie 2006:20; Van der Merwe 2014:373).

16.See Collins 2003; Monton 2009; Polkinghorne 2007a, 2009; see many more on Google books. 
decades should be exploited. Christian believers should be equipped not only to manage the change of the tide, but also to develop theology in relation to Scripture to cope with their intelligent newly critically asked questions for a better wellbeing (Van Der Merwe 2017:38).

\section{From demythologising to remythologising (2) Demythologising and Rudolph Bultmann}

All the events and developments over centuries that are referred to above certainly influenced Christianity. During the mid-20th century, on the theological level, it was the work of the most influential German scholar, Rudolf Bultmann, that rocked the church with his debate on Neues Testament und Mythologie (1941) (also Bultmann 1958), which vastly influenced the interpretation of Scripture (see Van Aarde 2011:1-11; Reeves 2005:n.p.). For almost 20 years this topic was debated 'by theologians, exegetes and philosophers of the most diverse backgrounds and convictions' (Salm n.d.:103).

According to Bultmann 'much of what the New Testament has to say is completely foreign to 'modern man', who thinks 'scientifically'; and because of this, many men will not accept any of it, for they are convinced that it is all of a piece that it is exclusively mythological' (Salm n.d.:104 referring to Kerugma und Mythos I, 22). He defines mythology as, '... the presentation of the otherworldly in terms of this world, and the divine in terms of human life; the presentation of the other side in terms of this side - for example, God's transcendence is expressed as spatial distance' (Salm n.d.:105 referring to Kerugma und Mythos I,22, n.2).

The world picture of the New Testament is mythical, and the redemptive event is presented in mythical language. The New Testament world is a three-story structure with the heaven above, the earth in the middle and hell at the bottom. Heaven is the place where God and the angels dwell; the underworld is hell, the dwelling place of Satan and demons - the place of torment. The earth is not simply the scene of the ordinary life of people, but rather a theatre for the activities of super-natural powers - God angels, as well as Satan and demons. These supernatural powers interfere in natural occurrences such as human thinking, willing and acting (see Bultmann 1989:1).

Corresponding to this mythical world-picture, is Jesus' redemptive event in mythical language.

The presentation of this redemptive event constitutes the content of the New Testament proclamation and relates to this mythical world picture. The proclamation occurs in mythological language: during the last days in the fullness of time, God sent his only Son. This Son was pre-existent; a divine being who incarnated on earth as a man. ${ }^{17}$ His crucifixion effected atonement for sinners. ${ }^{18}$ His resurrection

17.Galatians 4:4; Philippians 2:6ff.; 2 Corinthians 8:9; John 1:14, etc.

18.Romans 3:23-26; 4:25; 8:3; 2 Corinthians 5:14,19: John 1:29; 1 John 2:2, etc. is the beginning of the restoration of the cosmic catastrophe of death brought into the world by Adam. ${ }^{19}$ Through this event the demonic powers have also lost their power. ${ }^{20}$ The risen Jesus has been exalted to heaven and sits at the right hand of God,', he is declared 'Lord' and 'King' (Bultmann 1989:2).

For Bultmann resemblances of this pure mythological talk can be tracked to 1st-century contemporary mythology of Jewish apocalypticism and gnostic myth of redemption (cf. Bultmann 1989:2). Bultmann is of opinion that for the modern mind this is a mythical world picture of the past. The question that arises then, 'Is there any truth in the New Testament, a truth independent of this mythology, which can be accepted even though these mythical elements evidently cannot be believed?' For Bultmann, the nature of myth implies that such truth can exist. For the objective of myth is to express the understanding of oneself in the world in which one finds oneself. The objective is not an objective presentation of a true world picture. Myth expresses the origin and purpose of the world beyond the realm of known and physical reality. In fact, such a person can be delivered from the forces within the visible world that now dominate him (Salm n.d.:107 from Kerygma und Mythos, I:22f.).

\section{Bultmann (1958) then explains:}

[The] method of interpretation of the New Testament which tries to recover the deeper meaning behind the mythological conceptions as de-mythologizing. Its aim is not to eliminate the mythological statements but to interpret them. It is a method of hermeneutics'. (n.p.)

Therefore, Bultmann concurs that, because myth expresses a certain understanding of human existence, it is to be interpreted existentially. Consequently, the task is not a matter of elimination, but rather a matter of interpreting myths and interpreting them existentially. The nature and intention of myth requires such a kind of interpretation (Salm n.d.:107.)

This view and interpretation of Bultmann of the New Testament is exactly how many contemporary people view God and the New Testament. How then should we proceed? What is the message of the church in the 21st century?

\section{Remythologising and Kevin Vanhoozer ${ }^{22}$}

In his book, Remythologizing Theology, Vanhoozer (2010) attempts to solve this problem. He uses God's communicative action in Christ and in Scripture to deepen and refine the understanding of God's being; his relation to the world and his relation to human beings within it. His focal point is whether God has 'passions; and in what sense'. Is God 19.1 Corinthians 15:21-22; Romans 5:12ff.

20.1 Corinthians 2:6; Colossians 2:15; Revelation 12:7ff., etc.

21.Acts 1:6ff.; 2:33; Romans. 8:34, 1 John 2:1, etc.

22.See also Mladin (2011:221-249) in his appraisal of Vanhoozer's Communicative Theism. 
affected by any form of human action? If so, how then does he respond to it? (Poythress 2012:443).

For his modus operandi, Vanhoozer uses Bultmann's demythologising hermeneutics of reading scripture to introduce his title and approach in this monograph, Remythologizing Theology. Vanhoozer (2010) explains his understanding and use of remythologising:

Remythologizing is best defined in contrast to demythologizing as a type of first theology. It is a proposal for integrating exegesis, biblical theology, and systematic theology by attending to God's self-communication in the history and literature of Israel and the church and above all in the person and history of Jesus Christ. It is a way of viewing God, Scripture, and hermeneutics in terms of their mutual implications, all coordinated by the notion of communicative action: the triune God is the ultimate communicative agent of Scripture; Scripture is an element in the triune God's communicative action; interpretation is the way the church demonstrates her understanding of what God is saying and doing in and through Scripture by right theodramatic participation' (p. 30).

Vanhoozer regards it as essential that one returns to the biblical mythos and listens to it again. 'Always remythologising' means 'always returning' to the selfpresentation of God. This implies attending to the Trinitarian testimonies: 'those divine voice-breathed-words that unfold the mystery of the Word made flesh' (Vanhoozer 2010:475). 'Remythologising insists that God brings God to speech via the biblical mythos in a way that requires a measure of mystery and metaphysics alike' (Vanhoozer 2010:472). ${ }^{23}$

Van Aarde's understanding of the formulation of the biblical message in a post-secular age, although a year earlier than Vanhoozer's publication, relates to Vanhoozer's understanding. In his essay, Theological trends in our postsecular age, he discusses Ricoeur's sense of the word religare, which means 'to return', by referring to the church's returning as one that goes back in time. Van Aarde (2009) implies this:

Reliving it again today, as if for the first time, implies a de-construction, a re-telling in order to both reformulate and to retain.... This returning completes the circle. But completing the circle does not mean returning to the old beginning. It is a suspicious process which departs from the unacceptable and gives birth to new meaning. This presupposes a return by means of remembering ... the important narratives of the biblical and ecclesiastical past, especially that of Jesus and the church's proclamation of his kingdom message. (p. 6)

To interpret the Bible as relevant for today, the interpreter has to go beyond Vanhoozer's and Van Aarde's good proposals in addition to what Van Huyssteen has to contribute. His proposal does not contradict Vanhoozer's understanding of 'remythologising' and Van Aarde's 'de-con-struction', he rather compliments it. In his essay on Human origins and

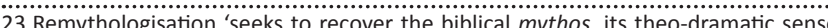
together with its theo-dramatic referent and to provide a coherent and appropriate conceptual elaboration of the ontology of the divine dramatis personae in terms of communicative agency' (Vanhoozer 2010:27). This definition by Vanhoozer is acceptable. But I want to add that this activity will consider the post-modern acceptable. But I want to add that this activity
situation in which we are embedded or a part of. religious awareness, Van Huyssteen (2005:104-105), a devotee in constructing plausible ways for theology, proposes an interdisciplinary approach. For him the entrance to an interdisciplinary conversation for theological reflection comprises three important steps. Firstly, theologians should acknowledge that their intellectual work was conducted in radical contexts and that traditions shaped and influenced the values that helped explain their reflection about God. Secondly, it comprises the notion of rationality that points towards conceivable forms of interdisciplinary dialogue. Thirdly, the resources that enable shared interdisciplinary dialogue are articulated by the notion of transversal rationality that also promotes legitimate ways of viewing the Christian's life.

\section{The amalgamation of the sciences with theology}

The application of Van Huyssteen's proposal of interdisciplinary dialogue in this essay is applied to the interdisciplinary amalgamation of the sciences to theology. ${ }^{24}$ The reality today is that many people still accept that we live in an age of two competing metanarratives on which our lives are based. On one side, the materialistic science speaks about 'deep time', 'evolutionary history' and a 'big bang'. Moreover, secular Western culture judges that the scientific worldview postulates the major interpretation of existence. ${ }^{25}$ On the other side, Christianity speaks of God as creator and relates the world to his 'Creation'. This assumes that a 'narrower' (literal) interpretation of scripture is required for biblical faith. Such a conflict model portrays the relation between science and theology as two competing narratives of life (O’Brien \& Harris 2012:147).

In spite of a scientific-saturated era, the church will definitely have to include the sciences in formulating its message if the message is to make sense. In this instance, theology and science should not be in contradiction to, but rather complementary with one another. This implies that the cognitive strategies of the sciences and theology will respect one another. Van Huyssteen (2005:105) questions whether science and theology can share in terms of their reasonable resources in spite of their fundamentally different reasoning strategies. It is believed that they can assist one another in identifying shared resources in different modes of knowledge, via interdisciplinary approaches. This will help them 'to reach beyond the boundaries of traditional disciplines in cross-contextual, cross-disciplinary conversation' (Van Huyssteen 2005:105).

This can be verified as follows: We are aware that the authors of the New Testament who can be regarded as the earliest Christian theologians, wrote in the environment of their heritage. From the perspective of concentric circles, contemporary Judaism is the primary influence. Secondly, Graeco-Roman culture lies in the varying degrees of 24.Also see Polkinghorne 2007a to verify the proposal of Van Huyssteen. 25.Even though science had most of its beginnings in a religious context, some scientists and philosophers argue that science somehow undermines all religious beliefs, and particularly belief in a creator God (Ward 2002:14). 
engagement. Their writings in these influences offer exceptional access to the Jesus narrative: his life, (Polkinghorne 2009:1) death and resurrection. They also provide an account of how the first followers of Jesus experienced and understood his teaching and life-transforming power. They believed that all this happened to them when the risen Jesus appeared to them, and subsequently, when the Holy Spirit (Paraclete) reminded and taught them, through the Church, revelation and salvation mediated through Jesus. This purports that all the writings of the New Testament and Old Testament of the Hebrew Bible create a biblical setting that is fundamentally important to all subsequent Christian thinking. 'Yet this acknowledgement of the unique significance of scripture is by no means enough to establish an unambiguous and sufficient context for theology' (Polkinghorne 2009:2) today.

In order to understand Polkinghorne's statement, let us consider an important remark once made by Wittgenstein. According to him (1998:31; also cf. Brümmer 2007:20), previous physicists are said to have promptly found that their mathematical understanding was too little to cope with physics. A similar claim could be made for the young people of today. They find themselves in situations where normal common sense no longer meets the eccentric demands emerging from life. Everything has become so complex that mastering it would require an exceptional intellect. A definite skill required to play a game is no longer enough. A fundamental question that keeps on coming up is: 'Can this game be played at all now and what would be the right game to play?' Can theologians still rely on scripture alone to interpret and understand its message and to make sense of it in a postmodern era?

Changing circumstances and demands of life promote cultural changes and consequently also changes of conceptual forms that people find adequate and that include related beliefs held to be true. According to Wiles (1967:9; quoted by Brümmer 2007:20), 'A statement whose truth or falsity can be determined only in terms of a world-view that is dead and gone can hardly be a statement of direct relevance to subsequent ages; old formulas ... conceived in another intellectual atmosphere no longer say what needs to be said or no longer say it suitably'. When considering the differences between various times, places and circumstances, the more we come to realise the truth and reality of the platonic claim that human thought is not principally absolute. Owing to variations in the exigencies of life, conceptual forms cannot endure infinitely sufficiently (Brümmer 2007:20).

A tendency that occurs is to think that the relationship between theology and science merely exists in terms of struggling with specific issues and problems. Hence, issues often raised relate to the creation of the universe, the origin(s) of the human race, the occurrence of suffering and so forth. The scientific context with its emphasis on intellectual thinking should, in fact, rather be recognised as providing a further opportunity to contribute more widely and to provide a greater insight into many aspects of existence. Obviously, specific frontline 'issues will always be significant foci for interaction, but the style of discourse appropriate to the science-and-religion perspective is also something to be accepted and valued in itself' (Polkinghorne 2009:8).

Unfortunately, the church, throughout its history, failed to consider what science has to propose with the appropriate respect and degree of seriousness that would help the church to acknowledge and succeed adequately in its contextual role. Fortunately, some contemporary theologians succeeded in paying attention to what science has to say and the contributions made by science. One of these theologians is the German Lutheran theologian, Pannenberg. He has stated emphatically that theology should not confine itself to life in the fideistic ghetto. Theology must interact with the whole of human knowledge, which includes the sciences. Pannenberg sought to engage extensively with the human and natural sciences. It is his belief that: If the God of the Bible is the creator and ruler of the universe, it becomes unthinkable to comprehend fully or even appropriately the processes of nature without any allusion to this God. Contrariwise, if nature and the universe can properly be understood without any reference to the God of the Bible, then this God cannot be the creator and ruler in nature and of the universe and can consequently not truly be God and trusted as the source of intelligent design, morality and life either (Pannenberg 1993:16; cf. Polkinghorne 2009:11-12).

Both science and theology are concerned with the pursuit for truth. Although these two disciplines focus on different dimensions of truth, they can surely complement one another rather than contrast one another. In both kinds of enquiry this truth will never be grasped totally and thoroughly (Polkinghorne 2007b:1) in isolation. Interdisciplinary interaction and experience is critically essential to the full pursuit of theological enquiry. If God is recognised as the source of all that exists, every kind of human intellectual investigation of reality must have something to contribute to any form of theological reasoning and any divine lived experiences. Such experiences pursue their goal of adequately coming to terms with the created world. This should be understood in terms of believing that the mind and purposes of the Creator lie behind cosmic order and history (Polkinghorne 2009:8-9).

At the beginning of a new millennium, modern science with its vast developments does necessitate a degree of reinterpretation to resonate with traditional Christian expression and articulation. Human knowledge of the universe has increased amazingly especially during the past three decades (cf. Ward 2002:10). A result, however, is that the scientific worldview actually sets mainstream Christian beliefs in a context that seems to bring out richer depths of meaning that have always been implicit in them. Christian beliefs provide avenues in which the universe, disclosed by the different sciences, can be conceivably seen and experienced to have meaning and purpose. Contrary to contrasting perceptions, there is a kind of 'natural fit' 
between the scientific worldview and mainstream Christian beliefs. This can enhance Christian faith in a highly scientific age (Ward 2002:11). Christianity has developed a sacred cosmology articulated in a convincing symbolic configuration, which expresses the themes mentioned above. This scientific cosmology provides the factual, literal and contextual background against which the spiritual vision of Christianity can be best perceived. Ward (2002:147151) deems Christianity as a religion of truly cosmic capacity, providing insight into the meaning and purpose of this universe. According to him, modern science has remarkably discovered the physical structure of this universe. This just shows one way in which faith in an unseen 'God' (Jn 1:18) can enrich physicists, biologists, anthropologists and so forth via the insights of a specific religious tradition of prayer and worship. With this in mind, it is very reasonable to believe that there is a creator God that rules this universe; and it should therefore be natural and appropriate to worship and pray to this God. From the above reasoning it becomes very clear that the assertions of Christianity transcend by far what the human reason can ascertain (Ward 2002:11). If the claims of Christianity are true, then it provides a more comprehensive understanding of the existent character of this striking and awesome universe (Ward 2002:12).

Against the above reasoning that the authors of the New Testament wrote within the environment of their heritage, the events surrounding Jesus' life can be understood as playing a key role in realising the divine purpose for this planet and universe. These events relate Jesus to and reflect the great cosmic themes of creation: divine love and divine life, uniting all things in the universe to the divine Logos. ${ }^{26}$ The Logos concept in the Gospel of John beautifully relates and resonates with quantum physics; and an amalgamation between the two can be facilitated by the Stoics' and Philo's perception of the Logos. Such a combination can make a huge contribution to the understanding of 'intelligent design' in creation and the acceptance that each celestial body in the universe has its own form of intelligence.

The scientific discovery of the significant intelligibility of the universe to rational enquiry should definitely be rendered intelligible by the church. This helps the church to interpret the intelligibility of the universe as the consequence of any human encounter with the mind of the Creator of the world. In fact, he is the One who is the (Polkinghorne 2009:12) true ground of the magnificent harmony, intelligence and order of the universe. If this is true, then the practising of science can be regarded as an aspect of the imago Dei (cf. Polkinghorne 2009:13).

26.According to Polkinghorne (2007b:109) is the theological doctrine of the Logos, as the divine Word, the original source of the 'rational order of creation'. This is evident from the phrase in the prologue of the Gospel of John who identifies the evident from the phrase in the prologue of the Gospel of John who identifies the
Word as the one 'by whom all things were made' $(1: 3)$ and 'the world came into being through him' (cf. 1:10). In John 1:9 the author also refers to the Word as enlightening everyone. In another passage, the apostle Paul identifies Christ as the enlightening everyone. In another passage, the apostle Paul identifies Christ as the
one by whom 'all things in heaven and earth were created' and in whom 'all things hold together' (Col 1:16-17).
According to many publications and opinions, it seems that the third millennium of Christian existence is heading towards a new amalgamation of scientific and religious thought. The vast development in the sciences over the past decade contributes to this integration. It implies the development of a global spirituality and a recovery of some of the deepest spiritual insights of the Christian faith, which have often been underemphasised or overlooked. ${ }^{27}$ The new understandings of the universe that science (physics \& cosmology) has brought have transformed many previous views of the universe (Ward 2002:14). In many new scientific publications, scientists agree that science contributes to an even greater sense to the wisdom and power of the creator. ${ }^{28}$

In Christianity, this creator or divine being is called God, Lord, Father and so forth Christians claim to find God in three main ways - revealed (Ward 2002:15) in history in the person of Jesus, present within human lives in the form of the Holy Spirit and transcendent in glory as the creator of all things and ruler over all things (cf. Ward 2002:16). This knowledge and experience of God in threefold form (as a trinity) constitutes a Christianity that is distinctive from all other religions. Similar to the experience that being in love with another person can fill life with a sense of purpose and meaningfulness, so can the experience of God provide courage, hope and joy to the whole of human life. God is not an entity open to inspection by any form of scientific technique. In fact, John 1:18 says that 'nobody has ever seen God'. Just as any person discloses something about his or her inner thoughts and purposes, equally God discloses the divine nature and mind of what and who God truly is. Christians believe that God is revealed through the macro cosmos, micro cosmos and dynamic cosmos, and they also assert that the God of the bible has revealed the divine identity in and through the human person of Jesus of Nazareth. They believe that Jesus is the most distinctive and authentic self-disclosure of God. In Jesus the divine identity became evident to be a supreme reality of self-giving, sharing and unitive love. This kind of love is believed to be communicated to humanity through him. In such knowledge and love, Christians believe that human life finds its ultimate purpose and fulfilment (Ward 2002:16).

If there is a purpose in the creation of this universe, it is most likely that an important part of it will unquestionably lie in specific events on this planet which reveal the nature and purpose of God. If then, there is an infinite intelligence behind the universe, it is reasonable to think that it has brought the universe into being for some purpose (Ward 2002:17). If God is the creator and ruler of this universe, it is

27.The Christian religion, like most human belief-systems, sometimes seem to be nothing but a matter of intolerant dogmas or narrow-minded moralising. But at its heart the Christian faith tries to teach people to turn from self-centredness, towards a sort of experience that will free them from anxiety and hatred and give a deeper sense of happiness and meaning. This experience Christians call the a deeper sense of happiness and meaning. This experience Christians call the awareness of a bein
self-centredness.

28.Ward (2002:15) also refers to those scientists who find it hard to relate the God who is for them a 'vast and almost incomprehensible cosmic intelligence' with the God of the bible who acted on this small planet in the life of a young Jewish God of the bible who acted on this small planet in the life of a young Jewish
preacher, who is the object of worship in churches and who has chosen odd people to communicate with. 
only to be expected and to be accepted that scientific discoveries about the universe will promote a deeper understanding of the nature and identity of the creator and/ or ruler of this universe. It is also to be expected that the God concept or God factor will provide the best explanation of why the universe is the way it is. This is a much better justification than a hypothetical denial of the existence of God. The modern scientific worldview and the Christian revelation can and should interact more effectively in the 21st century to provide a coherent and illuminating picture of human and divine existence in this extraordinary universe (Ward 2002:17).

The church of the 21st century shall have to adopt the contributions made by the sciences and adapt their message concerning the revelation of God and the salvation of human kind to remain relevant in their continuation of the missio Dei in a shattered world.

\section{Conclusion}

The objective of this essay was to point out that the church in its message shall have to incorporate the prolific findings of the sciences over the past decades to be relevant and have any impact on the world. The essay started to point out the dialectic between science and Christian religion over centuries. It also discussed how the postmodern era and post-secular paradigm prepared the church for a new spirituality. This preparation opened new avenues to incorporate the sciences to reformulate the Good News. The world has to be discerned through the observations and experiments that are necessary to determine what form the divine choice has taken. Paradise is NOT lost ... perhaps lost as myth but can now be re-mythologised from myth into a spiritual reality encapsulating scientific language as lived experience!

When Christians claim that the universe (and obviously the world) is created by God and also that God sustains and rules over the universe, it is an appropriate responsibility for Christians to scientifically study this universe. Polkinghorne (2007b:108; also Kirk 2007:217) refers to what scientists loved to say in the past: 'God wrote two books, the Book of Scripture and the Book of Nature. Both had to be read. When this was done well there could be no contradiction between them, because both had the same Author'. ${ }^{29}$ Bearing in mind everything evaluated in this essay, believers can certainly know that a divine plan existed. It is now the free responsibility of each person to recognise this divine plan and to embark on its implementation (Artigas 2000:124). It is the responsibility of the church to facilitate believers in this regard.

29. Kirchioffer (2003:26) quotes the statement of Galileo that refers to the close relation between Scripture and science: 'Holy Scripture and nature proceed alike from the divine World ... Everything that is said in the Bible is not bound by rules as strict as those which govern natural events, and God is no less excellently revealed strict as those which govern natural events, and God is no less excellently revealed in these than in the sacred pronouncements of Scripture' (Galileo, Letter to Christina of Lorraine, Opere di Galileo, Vol. V, pp. 316-317). Newton (Mathematical Principles, 2:391-392) wrote, "And thus much concerning God; to discourse of Who (see Snobelen 2004:573). According to Davies (1990:16), 'It may seem bizarre, but in my opinion science offers a surer path to God than religion ... I am convinced there is more to the world than meets the eye'.

\section{Recommendation}

In theological curricula at seminaries, a module on 'Science and Theology' can be incorporated in the discipline of Systematic Theology. Students should become familiar with this integration to answer and discuss the frequently asked questions regarding God, Christ, the universe, us and the future.

\section{Acknowledgement Competing interest}

The author declares that they have no financial or personal relationships which may have inappropriately influenced them in writing this article.

\section{Author's contributions}

D.G.v.d.M. is the sole contributor to this article.

\section{Funding}

This research received no specific grant from any funding agency in the public, commercial, or not-for-profit sectors.

\section{Data availability statement}

Data sharing is not applicable to this article as no new data were created or analysed in this study.

\section{Disclaimer}

The views and opinions expressed in this article are those of the author and do not necessarily reflect the official policy or position of any affiliated agency of the author.

\section{Ethical considerations}

This article followed all ethical standards for carrying out research without direct contact with human or animal subjects.

\section{References}

Artigas, M., 2000, The mind of the Universe: Understanding science and religion, Templeton Foundation Press, Philadelphia and London.

Beyers, J., 2014, 'The church and the secular: The effect of the post-secular on Christianity', HTS Theological Studies 70(1), 1-12. http://doi.org/10.4102/hts. v70i1.2605

Bird, M.F., Evans, C.A., Gathercole, S.J., Hill, C.E. \& Tilling, C., 2014, How God became Jesus. The real origins of belief in Jesus' divine nature -A response to Bart Ehrman, Zondervan, Grand Rapids, MI.

Brümmer, V., 2007, Speaking of a personal God: an essay in philosophical theology, Cambridge University Press, Cambridge.

Bultmann, R., 1958, Jesus Christ and mythology, SCM Press, London.

Bultmann, R., 1989, New Testament and mythology and other basic writings, Fortress Press, Philadelphia, PA.

Clayton, P., 2007, 'Boundaries crossed and uncross able: physical science, social science, theology', in K. Vanhoozer \& M. Warner (eds.), Transcending boundaries in philosophy and theology. Reason, meaning and experience, pp. 91-104, Ashgate Publishing, Hampshire.

Collins, 2006, The language of God. A scientist presents evidence for belief, Free Press, New York, NY.

Collins, C.J., 2003, Science \& faith. Friends or foes, Crossway Books, Wheaton, IL. Cvetkovic, V., 2001, 'An investigation of the concepts of logos in Greek philosophy and Christian thought', MA Dissertation, University of Durham. 
Davies, P., 1990, God and the new physics, Penguin Books, Victoria.

Flew, A. \& Varghese, R.A., 2007, There is a God. How the world's most notorious atheist changed his mind, HarperCollins e-Books.

Gould, P. (ed.), 2014, Beyond the control of God? Six views on the problem of God and abstract objects, Bloomsbury, New York.

Geaves, R. \& Chryssides, G.D., 2007, The study of religion: An introduction to key ideas and methods, Continuum Books, London.

Gibbons, A., 2017, 'Postmodernism is dead. What comes next?', Times Literary Supplement, viewed 02 February 2019, from https://www.the-tls.co.uk/articles/ public/postmodernism-dead-comes-next/.

Griffin, D.R., 1989, God and Religion in the postmodern world: Essays in postmodern theology SUNY series in constructive postmodern thought, State University of New York Press, New York.

Harris, M.J., 1992, Jesus as God: the New Testament use of Theos in reference to Jesus, Baker Books, Grand Rapids, MI.

Heyns, J.A., 1974, Op weg met die teologie, N.G. Kerkboekhandel, Pretoria.

Hovorun, C., 2013, 'Church and nation: Looking through the glasses of postsecularism', St Vladimir's Theological Quarterly 57(3-4), 423-430.

Hughes, G.J., 2005, The nature of God, Routledge, New York/London.

King, M., 2009, Postsecularism: The hidden challenge of extremism, James Clark \& Co, Cambridge.

Kirby, A., 2016, 'The death of postmodernism and beyond', Philosophy Now 58, 1-4 viewed 18 February 2019, from http://art-tech.arts.ufl.edu/ jack/home/ images/a/ae/DoPaB58.pdf.

Kirchhoffer, D., 2003, 'The good, the bad and those who think they are an investigation of the theology and science of Charity', St Augustine Papers 4(2), 1-17.

Kirk, J.A., 2007, The future of reason, science and faith. Following modernity and post modernity, Ashgate Publishing, Hampshire.

Kourie, C.E.T., 2006, 'The "turn" to spirituality', in P.G.R. De Villiers, C.E.T. Kourie \& C. Lombaard, The Spirit that moves (Acta Theologica, Supplementum 8), University of the Free State Press, Bloemfontein.

Lindberg, D.C. \& Numbers, R.L., 2003, When science \& Christianity meet, University of Chicago Press, Chicago.

Mahoney, J., 2011, Christianity in evolution. An exploration, Georgetown University Press, Washington DC.

Meyer, S.C., 2009, Signature in the cell. DNA evidence for intelligent design, HarperCollins e-Books.

Mladin, N., 2011, 'A remythologized theology? An appraisal of Kevin J. Vanhoozer's communicative theism', Perichoresis 9(2), 221-249.

Monton, B., 2009, Seeking God in science. An atheist defends intelligent design, Broadview, Toronto.

Newman, C.C., Davila, J.R. \& Lewis, G.S., 1999, Jewish roots for Christological monotheism. Papers from the St. Andrews Conference on the historical origins of the worship of Jesus, Brill, Leiden.

Numbers, R.L., 2003, 'Science without God: Natural laws and Christian beliefs', in D.C. Lindberg \& R.L. Numbers (eds.), When science and Christianity meet, pp. 265-286, University of Chicago, Chicago.

O'Brien, G.J. \& Harris, T.J., 2012, 'What on earth is God doing? Relating theology and science through biblical theology', Journal of the American Scientific Affiliation 64(3), 147-156.
Pannenberg, W., 1993, Toward a theology of nature: Essays on Science and Faith, John Knox Press, Westminster, KY.

Polkinghorne, J.C., 2007a, One world. The interaction of science and theology, Templeton Foundation Press, Philadelphia and London.

Polkinghorne, J.C., 2007b, Quantum physics and theology: an unexpected kinship, Yale University Press, New Haven and London.

Polkinghorne, J.C., 2009, Theology in the context of science, Yale University Press, New Haven and London.

Poythress, V.S., 2012, 'Kevin J. Vanhoozer. Remythologizing theology: Divine action, passion, and authorship', Westminster Theological Journal 74(2), 443-455.

Reeves, J., 2005, 'Rudolph Bultmann and demythologization', in H.W. Bartsch (ed.), Kerugma and myth by Rudolph Bultmann and five critics, n.p., Harper \& Row, New York.

Salm, C.L., n.d., Rudolph Bultmann's remythologizing of the New Testament, pp. 103-132, Manhatten College, New York, viewed 17 December 2018, from https:/ejournals.bc.edu/ojs/index.php/ctsa/article/download/2439/2072.

Snobelen, S.D., 2004, 'To discourse of God: Isaac Newton's heterodox theology and his natural philosophy', Studies in the History and Philosophy of Science 35, 573-603.

Taylor, C., 2007, 'What is secularity?', in K. Vanhoozer \& M. Warner (eds.), Transcending boundaries in philosophy and theology, pp. 57-76, Ashgate, Burlington.

Thiselton, A.C., 2004, Additional material: Can the Bible mean whatever we want it to mean? University College, Chester.

Turner, T., 1996, City as landscape: A post post-modern view of design and planning, Taylor \& Francis, London.

Van Aarde, A.G., 2009, 'Theological trends in a postsecular age', Verbum et Ecclesia 30(3), 1-8. https://doi.org/10.4102/ve.v30i3.178

Van Aarde, A.G., 2011, 'Rudolf Bultmann: His most influential contribution in the 20th century: "Urchristentum", "Jesus", "Commentary on John's gospel"?', HTS Theological Studies 67(3), 1-11.

Van Der Merwe, D.G., 2014, 'Eenheid as matriks van die spiritualiteit van die Evangelie volgens Johannes', Litnet Akademies 11(1), 372-400.

Van Der Merwe, D.G., 2017, 'The continuous dialectic between Theology and Culture: the critical functions of hermeneutics and spirituality in this dynamic discourse and their effects on wellbeing' in M. Miner \& M. Dowson (eds.), Spirituality, and their effects on wellbeing' in M. Miner \& M. Dowson (eds.), Spirituality,
culture and well-being, Centre for Human Interaction, Learning and Development, culture
Sydney.

Vanhoozer, K.J., 2010, Remythologizing theology: Divine action, passion and authorship, Cambridge University Press, Cambridge.

Van Huyssteen, J.W., 1997, Essays in postfoundational theology, Eerdmans, Grand Rapids, MI.

Van Huyssteen, J.W., 2005, 'Human origins and religious awareness: In search for human uniqueness', Studia Theologica 59, 104-128. https://doi.org/10.1080/ 00393380500339586

Vermeulen, T. \& Van Den Akker, R., 2010, 'Notes on metamodernism', Journal of Aesthetics and Culture 2(1), 1-14.

Vorster, K., 2012, 'Towards a post-secularist paradigm?', Studia Historiae Ecclesiasticae 38(2), 191-208. https://doi.org/10.1177/1368431016645821

Ward, K., 2002, God, faith and the new millennium, Oneworld Publications, Oxford.

Wiles, M., 1967, The making of Christian Doctrine, Cambridge University Press, Cambridge.

Wittgenstein, L., 1998, Culture and value, Blackwell, Oxford. 